\title{
Fracture-controlled fluid transport supports microbial methane-oxidizing communities at Vestnesa Ridge
}

\author{
Haoyi Yao ${ }^{1}$, Wei-Li Hong ${ }^{1,2}$, Giuliana Panieri ${ }^{1}$, Simone Sauer ${ }^{1,2}$, Marta E. Torres ${ }^{3}$, Moritz F. Lehmann ${ }^{4}$, \\ Friederike Gründger ${ }^{1}$, and Helge Niemann ${ }^{1,4,5,6}$ \\ ${ }^{1}$ Centre for Arctic Gas Hydrate (CAGE), Environment and Climate, Department of Geosciences, \\ UiT The Arctic University of Norway in Troms $\varnothing$, Troms $\varnothing$, Norway \\ ${ }^{2}$ Geological Survey of Norway (NGU), Trondheim, Norway \\ ${ }^{3}$ College of Earth, Ocean, and Atmospheric Sciences (CEOAS), Oregon State University, Corvallis, USA \\ ${ }^{4}$ Department of Environmental Sciences, University of Basel, Basel, Switzerland \\ ${ }^{5}$ Royal Netherlands Institute for Sea Research (NIOZ), Department of Marine Microbiology and Biogeochemistry, \\ and Utrecht University, den Burg, the Netherlands \\ ${ }^{6}$ Department of Earth Sciences, Faculty of Geosciences, Utrecht University, Utrecht, the Netherlands
}

Correspondence: Haoyi Yao (haoyi.yao@uit.no)

Received: 2 July 2018 - Discussion started: 13 August 2018

Revised: 8 March 2019 - Accepted: 9 May 2019 - Published: 29 May 2019

\begin{abstract}
We report a rare observation of a mini-fracture in near-surface sediments $(30 \mathrm{~cm}$ below the seafloor) visualized using a rotational scanning X-ray of a core recovered from the Lomvi pockmark, Vestnesa Ridge, west of Svalbard (1200 $\mathrm{m}$ water depth). Porewater geochemistry and lipid biomarker signatures revealed clear differences in the geochemical and biogeochemical regimes of this core compared with two additional unfractured cores recovered from pockmark sites at Vestnesa Ridge, which we attribute to differential methane transport mechanisms. In the sediment core featuring the shallow mini-fracture at pockmark Lomvi, we observed high concentrations of both methane and sulfate throughout the core in tandem with moderately elevated values for total alkalinity, ${ }^{13} \mathrm{C}$-depleted dissolved inorganic carbon (DIC), and ${ }^{13} \mathrm{C}$-depleted lipid biomarkers (diagnostic for the slow-growing microbial communities mediating the anaerobic oxidation of methane with sulfate - AOM). In a separate unfractured core, recovered from the same pockmark about $80 \mathrm{~m}$ away from the fractured core, we observed complete sulfate depletion in the top centimeters of the sediment and much more pronounced signatures of AOM than in the fractured core. Our data indicate a gas advectiondominated transport mode in both cores, facilitating methane migration into sulfate-rich surface sediments. However, the moderate expression of AOM signals suggest a rather re-
\end{abstract}

cent onset of gas migration at the site of the fractured core, while the geochemical evidence for a well-established AOM community at the second coring site suggest that gas migration has been going on for a longer period of time. A third core recovered from another pockmark along the Vestnesa Ridge Lunde pockmark was dominated by diffusive transport with only weak geochemical and biogeochemical evidence for AOM. Our study highlights that advective fluid and gas transport supported by mini-fractures can be important in modulating methane dynamics in surface sediments.

\section{Introduction}

Large-scale fractures are commonly observed on seismic profiles (Tobin et al., 2001; Weinberger and Brown, 2006; Plaza-Faverola et al., 2015) and can provide increased sediment permeability and conduits for fluid and gas transport. Macro-fractures were often observed in association with cold seep systems, where methane-rich fluids from greater sediment depth reach shallow sediments and may even be transported across the sediment-water interface (Berndt et al., 2014; Sahling et al., 2014). Prominent examples of fracturecontrolled fluid migration at cold seep systems include locations such as Hydrate Ridge (Torres et al., 2002; Weinberger 
and Brown, 2006; Briggs et al., 2011), Blake Ridge (Egeberg and Dickens, 1999), and the recently documented Storfjordrenna gas hydrate mounds in the Barents Sea (Hong et al., 2017b, 2018; Waage et al., 2019). Seepage at these locations can sustain high biomass levels of chemosynthetic communities that either directly oxidize methane or metabolize products of methane oxidation, such as sulfide (Boetius and Suess, 2004; Niemann et al., 2013). Fractures visible on seismic profiles often exceed $10 \mathrm{~m}$ in length (Gabrielsen et al., 1998). However, surface sediments may also feature smaller-scale, branched fracture networks (hereafter referred to as mini-fractures) which propagate from macro-fractures as the fluid pressure increases (Friedman, 1975; Briggs et al., 2011; Anders et al., 2014).

The role of small-scale fracture networks in routing methane upwards into the near-surface sediments is not well understood. In particular, the biogeochemical effects of minifractures in sediments with methane-dependent microbial communities is poorly constrained but is important for our understanding of how fracture networks influence microbial dynamics. Geochemically, fractures facilitate migration of deep fluids that are laden with electron donors from deeper sediments, which can then be used by sedimentary microbes as metabolic or bioenergetics substrates. To date, such minifractures have either been detected by X-ray images of cores under pressure (Riedel et al., 2006), or by the presence of macroscopic biofilms lining subseafloor fractures (Briggs et al., 2011). These biofilms were usually present at the sulfatemethane transition zone (SMTZ), where methane is oxidized by a consortium of anaerobic methanotrophic archaea (ANME) and sulfate-reducing bacteria (SRB) mediating the anaerobic oxidation of methane (AOM) with sulfate as the terminal electron acceptor (Knittel and Boetius, 2009):

$\mathrm{CH}_{4}+\mathrm{SO}_{4}^{2-} \rightarrow \mathrm{HCO}_{3}^{-}+\mathrm{HS}^{-}+\mathrm{H}_{2} \mathrm{O}$.

In contrast to large-scale transport pathways, mini-fractures are difficult to detect as they cannot be resolved with seismic tools (Emery and Myers, 1996; Gabrielsen et al., 1998) and may thus play an underappreciated but potentially important role in sediment methane dynamics, and the efficiency of the benthic microbial methane filter.

In this study, we report on the presence of a mini-fracture in the near-surface sediments of the active pockmark Lomvi, located on Vestnesa Ridge $\left(79^{\circ} \mathrm{N}, 6^{\circ} \mathrm{E}\right)$, west of the Svalbard archipelago. Using an interdisciplinary approach that combines geochemical and organic geochemical methods, we investigate the effects that such mini-fractures may impose on benthic methane dynamics and associated microbial communities. Our data show that mini-fractures can provide conduits for advective gas migration fostering AOM, but the moderate expression of AOM-associated biogeochemical signals along the mini-fracture at the Lomvi pockmark suggest a rather recent opening of this particular fracture.

\section{Material and methods}

\subsection{Study sites}

Vestnesa Ridge is NW-SE trending, $\sim 100 \mathrm{~km}$ long, and covered with $\sim 1 \mathrm{~km}$ thick contourite drifted sediments. Vestnesa Ridge features numerous pockmark structures (see a more detailed description of the geological setting in PlazaFaverola et al., 2015, and Panieri et al., 2017). This ridge is part of a submarine gas-hydrate system on the west Svalbard margin (1200 m water depth), where fluid and gas migration from deep hydrocarbon reservoirs towards the seafloor has potentially been ongoing since the early Pleistocene (Knies et al., 2018). Past investigations have shown that the ridge actively releases methane gas from the seafloor along the eastern segment of the structure (Bünz et al., 2012; Smith et al., 2014; Plaza-Faverola et al., 2015; Panieri et al., 2017), and seismic data suggest that seepage is related to intensive seabed faulting and rifting (Plaza-Faverola et al., 2015). The eastern part of Vestnesa Ridge features the pockmarks Lunde and Lomvi (Fig. 1), both belonging to the most active structures known in the area (Bünz et al., 2012; Panieri et al., 2017). Pockmarks are morphological expressions of fluid and/or gas eruptions from sediments, and are commonly observed in active hydrocarbon systems (Hovland et al., 2002). Pockmarks can be prominent in the seafloor bathymetry, ranging in shape from circular, crater-like edifices to "pushdown" sediment features (Hovland et al., 2002). Enhanced reflections and "push-down" features observed in the seismic transects of Lunde and Lomvi were interpreted as chimney structures containing free gas, which originate from beneath the bottom of the gas-hydrate stability zone (Bünz et al., 2012; Smith et al., 2014). Excessive pore pressure at the summit of this gas column fractured the sediments and led to the presence of free gas in the hydrate stability zone (Weinberger and Brown, 2006; Bünz et al., 2012).

\subsection{Sample collection}

We investigated three sediment cores from Vestnesa Ridge: two were collected by a multicorer (MC) during cruise CAGE15-2 with R/V Helmer Hanssen in 2015 (core Lomvi $893 \mathrm{MC}$ and core Lunde 886MC), and an additional push core (core Lomvi 008PC) was recovered with the remotely operated vehicle (ROV) Ægir about $80 \mathrm{~m}$ away from core Lomvi 893MC during the P1606 cruise with R/V G.O. Sars in 2016 (Table 1). The MC system used during cruise CAGE15-2 can collect up to six parallel cores during every deployment, and a MISO (Multidisciplinary Instrumentation in Support of Oceanography, Woods Hole Oceanographic Institution) towcam was attached to the MC frame, allowing targeted videocontrolled sampling (Panieri et al., 2015, 2017). Among the six cores, one was subsampled for porewater analyses, and two adjacent cores were used for lipid biomarker and headspace gas analyses, respectively. The cores for porewater 




Figure 1. Regional multibeam bathymetric map of Vestnesa Ridge showing the Lunde and Lomvi pockmarks and sampling locations. Locations of multicores and push cores used in this paper are denoted as stars.

extraction were used for X-ray analysis. Core Lomvi 893MC was collected at a site with bacterial mats around outcropping carbonate crusts at the Lomvi pockmark, whereas core Lunde $886 \mathrm{MC}$ was collected at a soft sediment site with patchy bacterial mats and tubeworms at the Lunde pockmark (Figs. 1 and 2). The push core Lomvi 008PC was recovered from a large patch of bacterial mat at the Lomvi pockmark. This core was only sampled for the analysis of porewater and lipid biomarkers (limited sample material impeded the analysis of the gas composition from Lomvi 008PC).

Immediately upon recovery, we subsampled the cores for subsequent gas, porewater, and biomarker analyses. Details on headspace sampling and gas analysis in the multicores were described in Panieri et al. (2017) and references therein. Briefly, $5 \mathrm{~mL}$ of bulk sediments were sampled into a $20 \mathrm{~mL}$ headspace glass vial, containing $5 \mathrm{~mL}$ of $1 \mathrm{M} \mathrm{NaOH}$ and two glass beads. The gas analysis was performed with a ThermoScientific Trace 1310 gas chromatograph (GC) equipped with a TG-BOND alumnia $\left(\mathrm{Na}_{2} \mathrm{SO}_{4}\right)$ column $(30 \mathrm{~m} \times 0.53 \mathrm{~mm} \times 10 \mu \mathrm{m})$. The methane headspace samples were obtained on a parallel core as the fractured core in the same set of the multicorer frame. Porewater was extracted at ambient temperature (ca. $-1{ }^{\circ} \mathrm{C}$ ), at a resolution of $2 \mathrm{~cm}$, with either $10 \mathrm{~cm}$ (Lomvi 893MC and Lunde $886 \mathrm{MC}$ ) or $5 \mathrm{~cm}$ rhizon samplers (Lomvi 008PC) attached to acid-cleaned syringes (Seeberg-Elverfeldt et al., 2005). Rhizon membranes were soaked in Milli-Q water before use. The first $0.5 \mathrm{~mL}$ of the recovered porewater was discarded to avoid dilution or contamination with residual Milli-Q water in the rhizons. Sediment samples for biomarker analyses were collected on board with a methanol pre-cleaned spatula at a resolution of $2 \mathrm{~cm}$, wrapped in aluminum foil and subsequently stored frozen at $-20^{\circ} \mathrm{C}$ until analysis. Intact sediment cores were kept at $4{ }^{\circ} \mathrm{C}$ for further X-ray analysis in onshore laboratories using a Geotek MSCL-XCT at UiT.

\subsection{Porewater analyses}

Total alkalinity (TA) was measured on board using the Gran titration method (Grasshoff et al., 1999) within a few hours after the syringes were disconnected from the rhizon samplers. The $\mathrm{HCl}$ titrant $(0.012 \mathrm{M})$ was checked daily on board with local surface seawater and $10 \mathrm{mM}$ of borax to verify the acid concentration. The $\mathrm{pH}$ meter of the titrator was calibrated with $\mathrm{pH}$ standard solutions ( $\mathrm{pH}$ of 4,7 , and 11) both before and during the cruise. Porewater aliquots $(2 \mathrm{~mL})$ for sulfate analysis were preserved with $3 \mathrm{~mL}$ zinc acetate solution $(23 \mathrm{mM})$ to precipitate the dissolved sulfide (Gieske et al., 1991; Grasshoff et al., 1999) for CAGE 15-2 samples. All sulfate analyses were performed using a Dionex ICS1100 Ion Chromatograph equipped with a Dionex IonPac AS23 column at the Geological Survey of Norway (NGU) (Sauer et al., 2016). For sulfide concentration measurements, the precipitated zinc sulfide was quantified in the onshore geology laboratory at UiT with a spectrophotometric method (Cline, 1969) using a UV-1280 UV-vis Spectrophotometer (Shimadzu). The amount of zinc acetate added to samples from core 008PC was too low to precipitate all dissolved sulfide; thus the measured sulfide concentrations are minimum values. For the subsequent measurement of $\delta^{13} \mathrm{C}$ of dissolved inorganic carbon (DIC), $2 \mathrm{~mL}$ aliquots of porewater were fixed on board with saturated $\mathrm{HgCl}_{2}$ (27 mM final concentration) (Grasshoff et al., 1999). The $\delta^{13} \mathrm{C}$ DIC of CAGE 15-2 samples (Bernhard and Panieri, 2018) were analyzed using a Finnigan DELTA-Plus mass spectrometer coupled to a GasBench II as described in Torres et al. (2005). The $\delta^{13} \mathrm{C} \mathrm{DIC} \mathrm{in}$ pore waters of core Lomvi 008PC was determined from the $\mathrm{CO}_{2}$ liberated from the water after acidification with phosphoric acid. Measurements were carried out at EAWAG (The Swiss Federal Institute of Aquatic Science and Technology) using an IRMS (Isotope Ratio Mass Spectrometer, Isoprime) equipped with a Gilson 222XL Liquid Handler and a Multiflow unit (Isoprime). The standard deviation of the $\delta^{13} \mathrm{C}$ DIC measurements from repeated measurements of standards was $\pm 0.1 \%$ o $(1 \sigma, n=27)$. The stable carbon isotope values for DIC are reported in the conventional $\delta$ notation in per mill $(\%)$ relative to V-PDB (Vienna Pee Dee Belemnite).

\subsection{Lipid extraction, quantification, identification, and determination of compound-specific stable carbon isotope composition}

Lipid biomarkers were extracted and analyzed according to previously reported protocols (Elvert et al., 2003) with modification for alcohol derivatization (Niemann et al., 2005) and instrument setup (Blees et al., 2014; Steinle et al., 2018). Briefly, a total lipid extract (TLE) was obtained by ultrasonication of $\sim 20 \mathrm{~g}$ wet sediment samples in four extraction 
Table 1. Information on coring stations, coring coordinates, seafloor habitat information, and analyses performed at each site. DIC: dissolved inorganic carbon; TA: total alkalinity; conc.: concentration; NA - not available.

\begin{tabular}{|c|c|c|c|}
\hline Pockmark (cruise) & $\begin{array}{l}\text { Lomvi } \\
\text { (CAGE15-2) }\end{array}$ & $\begin{array}{l}\text { Lomvi } \\
\text { (P1606) }\end{array}$ & $\begin{array}{l}\text { Lunde } \\
\text { (CAGE15-2) }\end{array}$ \\
\hline Core & Lomvi 893MC & Lomvi 008PC & Lunde $886 \mathrm{MC}$ \\
\hline \multirow[t]{2}{*}{ Coordinates } & $79^{\circ} 0.180^{\prime} \mathrm{N}$ & $79^{\circ} 0.162^{\prime} \mathrm{N}$ & $79^{\circ} 0.366^{\prime} \mathrm{N}$ \\
\hline & $6^{\circ} 55.434^{\prime} \mathrm{E}$ & $6^{\circ} 55.488^{\prime} \mathrm{E}$ & $6^{\circ} 54.030^{\prime} \mathrm{E}$ \\
\hline Habitat & bacterial mats and carbonate crusts & bacterial mats & tubeworms \\
\hline Methane & methane headspace & NA & methane headspace \\
\hline Porewater analyses & sulfate, sulfide, TA, $\delta^{13} \mathrm{C}$ DIC & sulfate, sulfide, TA, $\delta^{13} \mathrm{C}$ DIC & sulfate, sulfide, TA, $\delta^{13} \mathrm{C}$ DIC \\
\hline Lipid biomarkers & conc. and $\delta^{13} \mathrm{C}$ & conc. and $\delta^{13} \mathrm{C}$ & conc. and $\delta^{13} \mathrm{C}$ \\
\hline
\end{tabular}
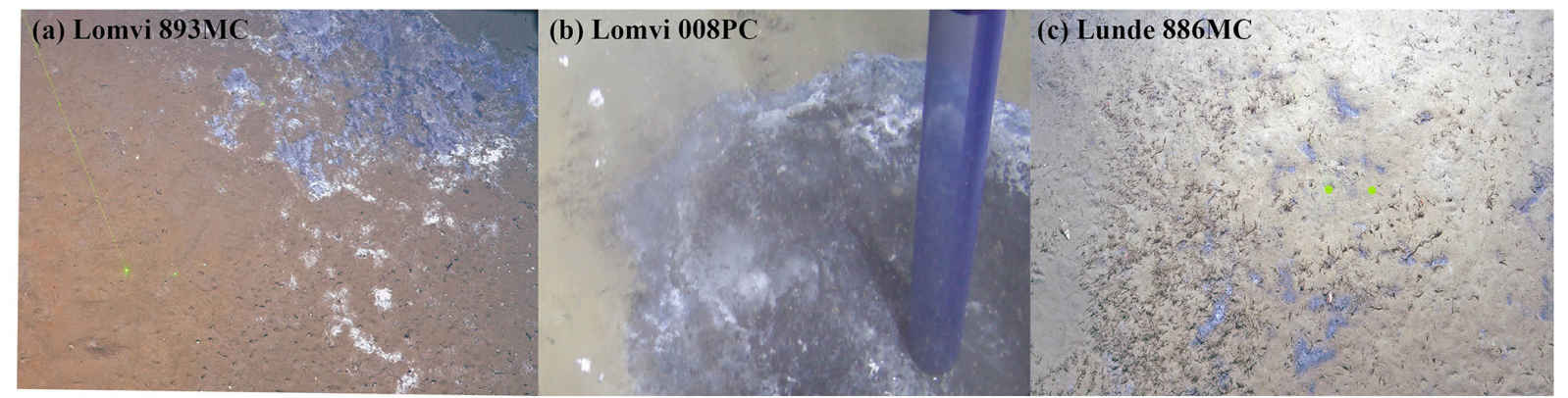

Figure 2. Still images of the seafloor before launching of the multicorer at coring site Lomvi 893MC (a) and coring site Lunde 886MC (c), as well as during ROV guided push coring at coring site Lomvi 008PC (b). Coring site Lomvi 893MC (a) and 008PC feature bacterial mats and reduced, black sediments, while the coring site Lunde $886 \mathrm{MC}$ (c) is characterized by soft sediments with tubeworms and small patchy bacterial mats. Green laser points (a, c) are $20 \mathrm{~cm}$ apart and the diameter of the push core (b) is $8.5 \mathrm{~cm}$.

steps with solvents of decreasing polarity: dichloromethane (DCM) / methanol (MeOH) 1:2; DCM/MeOH 2:1; and DCM for the last two extraction steps. The TLE was then saponified, and a neutral lipid fraction was extracted prior to methylation of the remaining polar fraction (comprising free fatty acids) to yield fatty acid methyl esters (FAMEs) for chromatographic analysis. Double bond positions of FAMEs were determined by analyzing dimethyl-disulfide adducts (Nichols et al., 1986; Moss and Lambert-Fair, 1989). The neutral fraction was further separated into hydrocarbons, ketones, and alcohols, the latter of which was derivatized to form trimethylsilyl adducts for analysis.

Individual lipid compounds were analyzed using a GC (Thermo Scientific TRACE ${ }^{\mathrm{TM}}$ Ultra), equipped with a capillary column (Rxi- $5 \mathrm{~ms}, 50 \mathrm{~m}, 0.2 \mathrm{~mm} \mathrm{ID}, 0.33 \mu \mathrm{m} d_{\mathrm{f}}$ ), using helium gas as a carrier gas at a constant flow rate of $1 \mathrm{~mL} \min ^{-1}$. The initial oven temperature was set to $50^{\circ} \mathrm{C}$, held for $2 \mathrm{~min}$ and then increased to $140^{\circ} \mathrm{C}$ at a rate of $10^{\circ} \mathrm{C} \mathrm{min}^{-1}$, held for $1 \mathrm{~min}$, then further increased to $300^{\circ} \mathrm{C}$ at $4{ }^{\circ} \mathrm{C} \mathrm{min}-1$. The final hold time was $63 \mathrm{~min}$ to analyze FAMEs or $160 \mathrm{~min}$ to analyze larger (i.e., high boiling point) lipids in the hydrocarbon and alcohol fractions. Concentrations were determined by flame-ionization detection (FID) against internal standards. Unknown compounds were identified with a quadrupole mass spectrometry unit (Thermo Sci- entific DSQ II) at the chromatography periphery. Similarly, compound-specific stable carbon isotope ratios were determined using a magnetic sector isotope ratio mass spectrometry unit (Thermo Scientific Delta V Advantage) coupled to a gas chromatography setup with the above-outlined specification. $\delta^{13} \mathrm{C}$ values are reported with an analytical error of $\pm 1 \%$.

\section{Results and discussion}

\subsection{Sediment X-ray imaging and porewater geochemistry}

Our detailed X-ray imaging of cores retrieved from locations of known methane seepage in Vestnesa Ridge revealed a mini-fracture in the core Lomvi $893 \mathrm{MC}$ in the top $30 \mathrm{~cm}$ (Fig. 3) but not in any other core. However, it is important to note that X-ray imaging can only confirm the presence of a fracture while the size or expansion of the original fracture cannot be resolved. Upon recovery, core Lomvi 893MC showed extensive gas ebullition. Thus it is possible that the fracture expanded during core retrieval because of pressureinduced volume changes in sedimentary gases. Nevertheless, our analyses revealed a substantial increase in methane concentrations in the upper section of the core (Fig. 4), which is 


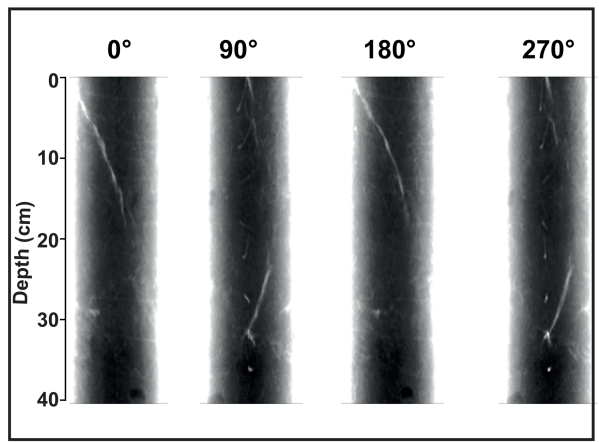

Figure 3. X-ray images of core Lomvi 893MC. The different rotational planes show a whitish X-ray transparency extending throughout the core. This zone is interpreted as a zone of weakness facilitating fluid and gas migration in situ. The void probably became gas filled after core recovery. A rotational video of this core is available in the Supplement.

an uncommon observation in marine settings where methane originates at greater sediment depth (i.e., methane concentrations typically increase downcore). We argue that the higher concentration at the surface of the core directly indicates an advective (fracture controlled) influx of methane into the top sediment section at the coring side of the core Lomvi 893MC. Typically, high methane concentrations in marine sediments lead to elevated rates of AOM, which in return lead to sulfate depletion and sulfide production, and thus the development of a sulfate methane transition zone (SMTZ). Furthermore, excess production of DIC during AOM leads to elevated sediment TA and low $\delta^{13} \mathrm{C}$ DIC values. The marked methane increase at coring site Lomvi 893MC was not paralleled by changes in other parameters, which are commonly associated with AOM (Fig. 4a). Rather, the smooth porewater profiles of sulfate, sulfide, TA, and $\delta^{13} \mathrm{C}$ of DIC in this core seem typical for locations with low methane input, as often found in settings characterized by diffusive transport regimes (Treude et al., 2003; Egger et al., 2018; Niemann et al., 2009). We attribute this apparently contradictory observation of enhanced methane concentrations on the one hand and the rather "inconspicuous" signals for AOM activity on the other to a recent genesis of the fracture (see additional discussion below). To further investigate the changes associated with the highly heterogeneous nature of the methane dynamics in this region, we compared this first core with two additional cores from contrasting settings at Vestnesa Ridge.

The push core Lomvi 008PC retrieved from an active venting site (ca. $80 \mathrm{~m}$ to the SE of core Lomvi 893MC) at the Lomvi pockmark showed sulfate depletion within the first $5 \mathrm{~cm}$ b.s.f. (below the sea floor) (Fig. 4b), indicating a high methane flux and a shallow SMTZ (Reeburgh, 2007). This shallow SMTZ is comparable to those typically observed at locations of high methane flux, such as the Beggiatoa fields at Hydrate Ridge (Treude et al., 2003), the Gulf of Mexico
(Ussler and Paull, 2008), or Haakon Mosby Mud Volcano (Niemann et al., 2006a, b). At these high-flux sites, AOM rates have been estimated to be on the order of several millimoles per square meter per day. A third core (core Lunde $886 \mathrm{MC}$ ) was retrieved from a soft-sediment site characterized by the extensive occurrence of tubeworms and bacterial mats (Fig. 2) at the adjacent active Lunde Pockmark. Sulfate concentrations in this core showed only a moderate decrease with sediment depth and traces of methane were detected in the upper $20 \mathrm{~cm}$ of the core (Fig. 4c). These data are consistent with observations of low sulfide concentrations and TA. Together, our results indicate a substantially lower methane flux and efficient methane retention through AOM in sediments at this coring site, similar to previous findings from seep sites characterized by macrofauna-inducing bioventilation (e.g., Niemann et al., 2006a, b; Levin et al., 2016). Although core Lunde $886 \mathrm{MC}$ is located in a diffusive system, the convex shape of the sulfate concentration profile along with increasing methane concentration at the bottom suggest non-steady-state conditions. The convex shape of the sulfate profile can be related to an ongoing increase in methane flux (Fischer et al., 2013; Hong et al., 2017b). It may also be related to the intrusion of seawater into the shallower sediments, which can be induced by bioventilation, and/or ascending methane bubbles from the sub-seafloor (Haeckel et al., 2007; Hong et al., 2016). Our visual investigations of the seafloor revealed the presence of tubeworms but there are a few bivalves; therefore bioventilation would be moderate. Methane concentration in the upper sediment section was very low, and we did not observe methane bubbles emanating from the seafloor at the coring site. We thus assume that moderate bio-irrigation and a recent increase in the diffusive methane flux at the coring site (Lunde 886MC) can explain the non-steady-state sulfate and methane profiles in the Lunde pockmark core.

\subsection{Methanotrophic community development}

To further investigate the role of the detected mini-fracture in core Lomvi $893 \mathrm{MC}$ on the biogeochemistry and microbial community, we investigated archaeal and bacterial lipid biomarkers and their associated stable carbon isotope signatures that are diagnostic for AOM communities (Niemann and Elvert, 2008, and references therein). ANMEs typically produce a suite of glycerol ether lipids comprising isoprenoidal alkyl moieties that may also occur as free hydrocarbons in environmental samples. We found the isoprenoidal dialkyl glycerol diethers archaeol and $s n 2$-hydroxyarchaeol in all three cores (Fig. $4 \mathrm{a}-\mathrm{c}$ ). Furthermore, the ${ }^{13} \mathrm{C}$-depleted signatures of these compounds provide evidence that their source organisms mediate sulfate-dependent AOM. Indeed, ANME biomass is characterized by a strongly ${ }^{13} \mathrm{C}$-depleted isotope composition because the metabolized methane is typically ${ }^{13} \mathrm{C}$-depleted, and $\mathrm{AOM}$ is associated with a strong kinetic isotope effect (Whiticar, 1999). The sulfate-reducing 

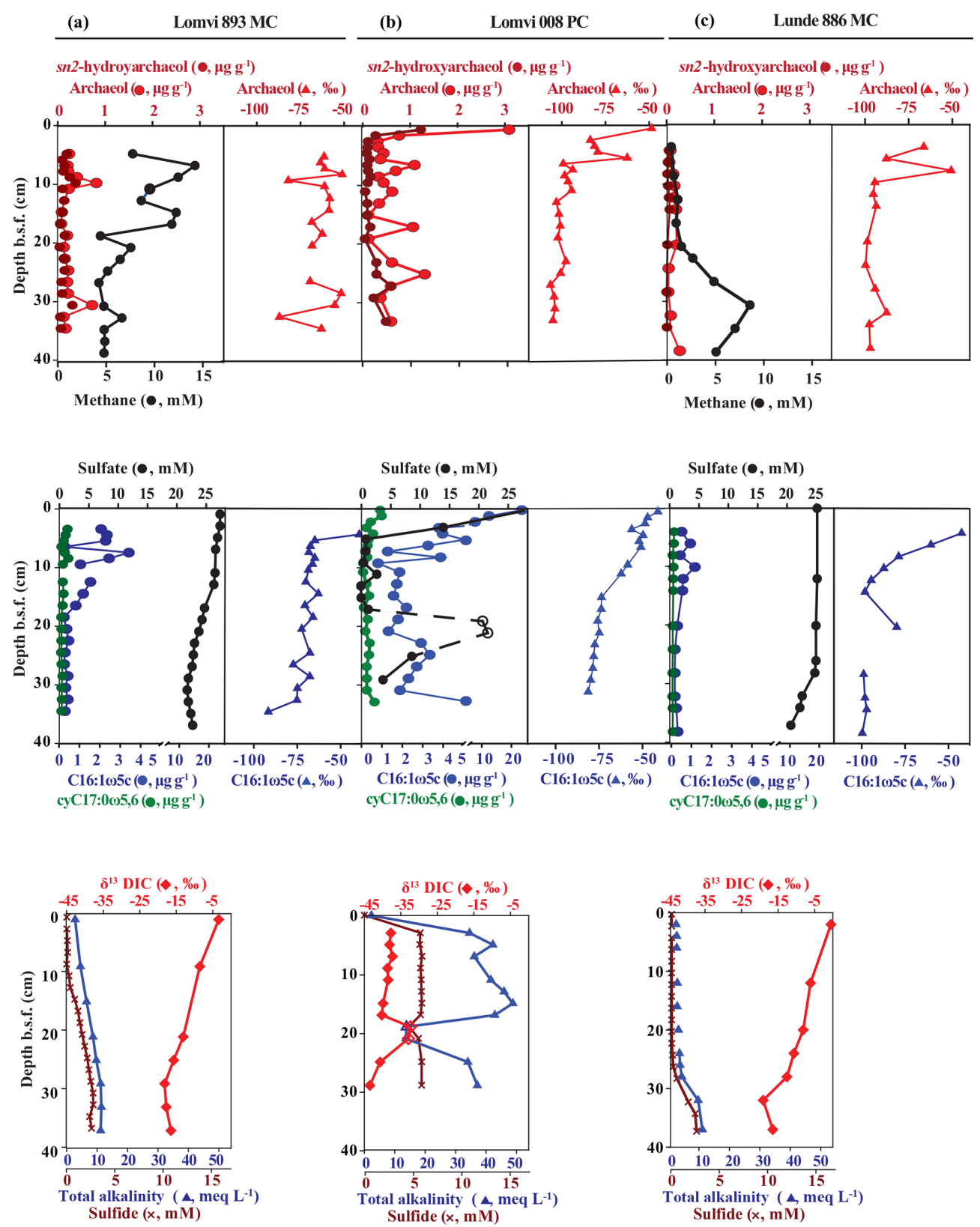

Figure 4. Biogeochemical profiles of archaeal (sn2-hydroxyarchaeol, archaeol) and bacterial lipid biomarkers (fatty acids $\mathrm{C} 16: 1 \omega 5 \mathrm{c}$,

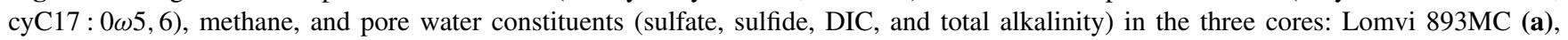
Lomvi 008PC (b) and Lunde 886MC (c).

partner bacteria involved in AOM produce characteristic fatty acids $(\mathrm{C} 16: 1 \omega 5 \mathrm{c}$, and $\mathrm{cyC} 17: 0 \omega 5,6)$ which we observed at relatively high concentrations (Fig. $4 \mathrm{a}-\mathrm{c})$. As these bacteria incorporate ${ }^{13} \mathrm{C}$-depleted DIC produced by the anaerobic methanotrophs (Wegener et al., 2008), their stable carbon isotope signature was also depleted in ${ }^{13} \mathrm{C}$. The biomarker data are consistent with an active AOM microbial population at all Vestnesa Ridge sites.

Our data also show, however, clear differences in the abundance of AOM-derived lipids at the three investigated coring sites (Fig. 4a-c). To highlight these differences, we calculated average concentrations and the isotopic depletion of archaeol and fatty acid C16: $1 \omega 5 \mathrm{c}$ (i.e., typical ANME and associated SRB lipids) relative to source methane $\left(\Delta \delta^{13} \mathrm{C}\right.$ values) and compared these values to a non-seeping reference site south of Svalbard (Yao et al., 2017) and a known high methane flux site at Hydrate Ridge (Elvert et al., 2005) (Fig. 5). We chose Hydrate Ridge as the high flux comparison site because the only other observation of a mini-fracture was documented from that location (Briggs et al., 2011). We 

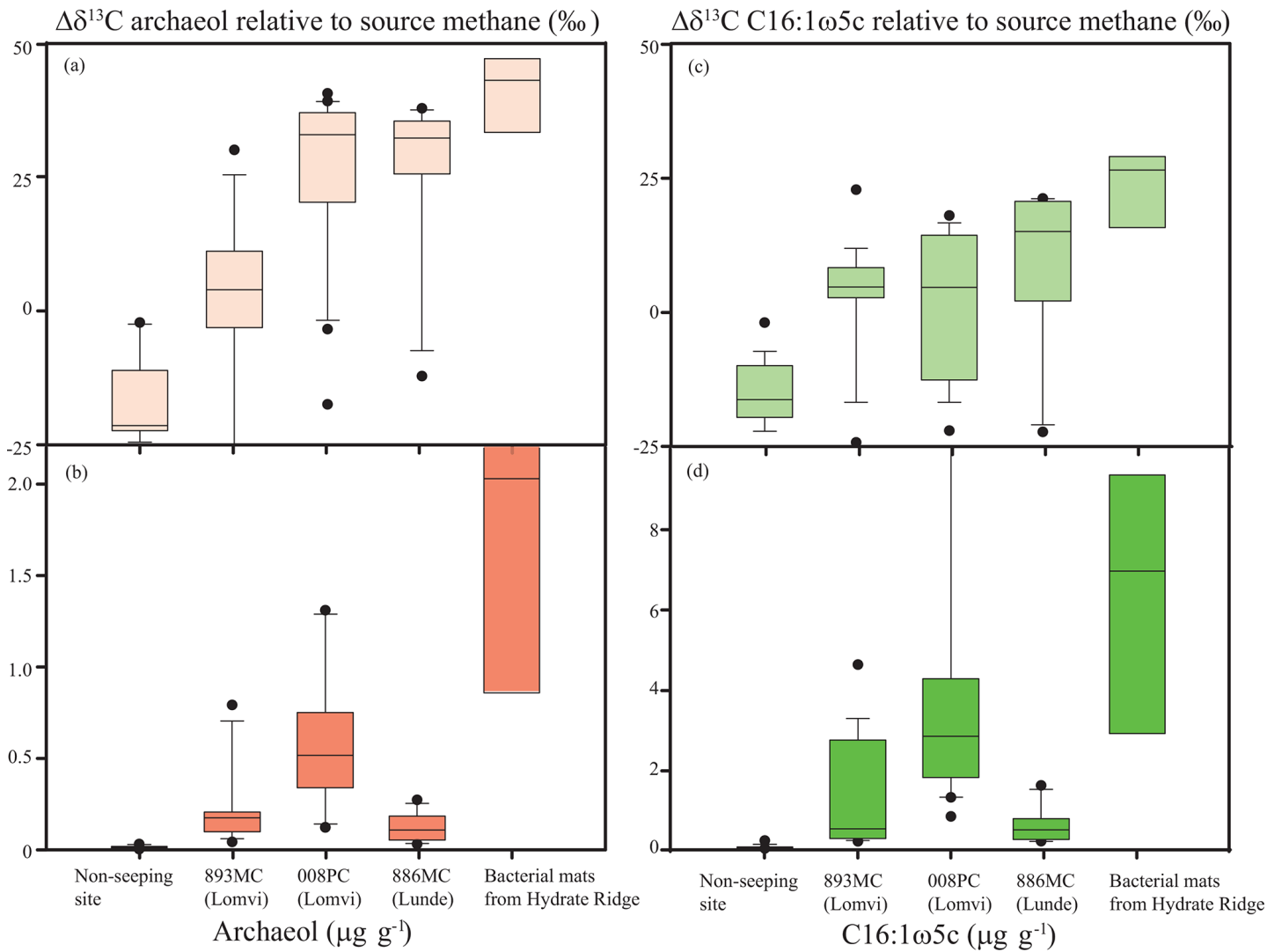

Figure 5. Average lipid biomarker concentrations and isotopic differences to source methane of the archaeal lipid archaeol $\left(\Delta \delta^{13} \mathrm{C}\right)(\mathbf{a}, \mathbf{b})$ and the bacterial fatty acid C16 : $1 \omega 5 \mathrm{c}(\mathbf{c}, \mathbf{d})$. Cores Lomvi $893 \mathrm{MC}$ (averaged from $0-35 \mathrm{~cm}$ ), Lomvi 008PC (averaged from 0-33 cm), and Lunde 886 MC (averaged from 0-38 cm) are compared to a high flux site at Hydrate Ridge (Elvert et al., 2005) and a core from a non-seeping site south of Svalbard (1522GC, $76.107^{\circ} \mathrm{N}, 15.957^{\circ} \mathrm{E}$, averaged from 0-350 cm; Yao et al., 2017).

found the lowest concentrations of the diagnostic lipids at the non-seeping reference site, followed by the core Lunde 886MC, the core Lomvi 893MC, the core Lomvi 008PC, and finally the Hydrate Ridge core. The substantially higher concentration of AOM-derived lipids at the Lomvi (particular in core Lomvi 008PC) compared to the Lunde site (core Lunde $886 \mathrm{MC}$ ) is consistent with the geochemical signals of $\mathrm{AOM}$ (e.g., sulfate, sulfide, $\delta^{13} \mathrm{C}$ of DIC) in the respective cores. The differences in concentrations of diagnostic lipids suggest a high standing stock of AOM communities in core Lomvi 008PC, and a much lower one in the other two cores. AOM communities grow very slowly, with doubling times of several months (Nauhaus et al., 2007; Zhang et al., 2011; Timmers et al., 2015). A sudden increase in methane flux and methane concentrations in the sulfate-rich sediments, which comprise only a small initial standing stock of AOM microorganisms, may eventually lead to elevated AOM activity, but with a significant lag time of several months to years. Our biomarker data suggest that the methanotrophic community at coring site Lomvi 893MC was not well developed, indicating that the increase in methane concentrations at that site occurred rather recently, probably less than a few years prior to our sampling campaign. We found a more mature AOM community at the site Lomvi 008PC. Similarly, the previous findings of biofilms associated with the mini-fracture at Hydrate Ridge (Briggs et al., 2011) indicate a more mature AOM community at this site. This suggests that the methane flux was higher at these sites for a longer period of time, allowing for the establishment of the slow-growing AOM community.

Because of the spatial dynamics of venting at the Lomvi pockmark in Vestnesa Ridge (Bohrmann et al., 2017; Hong et al., 2017a, b; Panieri et al., 2017), it is likely that the biomarker results reflect the cumulative history of microbial AOM activity, rather than solely the most recent situation. Nonetheless, we observed a general decrease in $\delta^{13} \mathrm{C}$ of both bacterial and archaeal lipids in horizons of present-day sulfate depletion, indicating a higher contribution of AOMderived compounds to the lipid pool. Such a decrease in $\delta^{13} \mathrm{C}$ was apparent at $\sim 10 \mathrm{~cm}$ b.s.f. in Lomvi 893MC where sulfide started to accumulate, at $\sim 5 \mathrm{~cm}$ b.s.f. in core Lomvi $008 \mathrm{PC}$ where sulfate was depleted, and at $10-15 \mathrm{~cm}$ b.s.f. in Lunde $886 \mathrm{MC}$ where methane began to increase downcore (Fig. 4). At these depths, the ratios of sn2-hydroxyarchaeol 


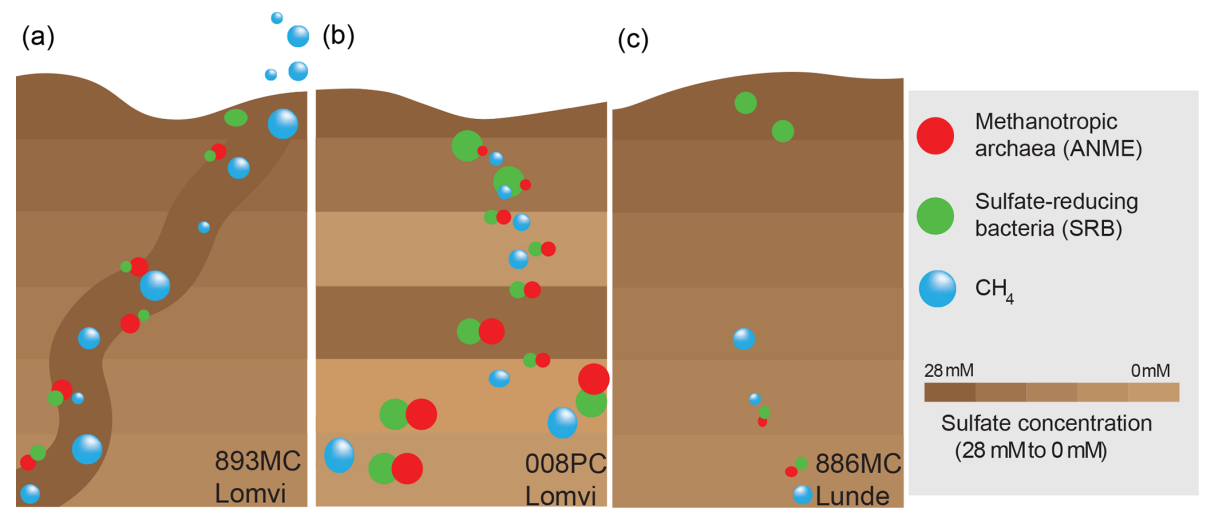

Figure 6. Schematic illustration of different methane transport modes in the study area (big bubble and circle sizes highlight high methane concentrations and the approximate size of the standing stocks of AOM communities, respectively). Low amounts of methane in a diffusiondominated setting sustain a weakly defined AOM microbial community (c). Mini-fracturing enhances the methane availability and fosters AOM community growth (a). The AOM community is fully developed after advective methane transport has continued for a longer period of time (b).

to archaeol were 0.98 (core Lomvi 893MC), 0.37 (core Lomvi 008PC), and 0.26 (core Lunde 886MC), indicating that ANME-1 is likely to be a key AOM organism at all the investigated coring sites (Niemann and Elvert, 2008). The known SRB types associated with ANME-1 and ANME-2 belong to the Deltaproteobacteria, Desulfosarcina/Desulfococcus clade Seep-SRB1, which typically display distinct ratios of the fatty acids $\mathrm{C} 16: 1 \omega 5 \mathrm{c}$ relative to isoC15:0. In systems dominated by Seep-SRB1 associated with ANME-1 this value is commonly $<2$, while it is $\gg 2$ in systems where Seep-SRB-1 is associated with ANME2 (Niemann and Elvert, 2008). At all coring locations, this biomarker ratio was $>2$ (3.2, core Lomvi 893MC; 5.4, core Lomvi 008PC; 7.9, core Lunde 886MC), which is indicative of an SRB eco-type associated with ANME-2 rather than ANME-1. At this point, we can only speculate about these contradicting lipid patterns, and additional DNA-based tools would be needed to further identify the key AOM microbes at the investigated sites.

The ${ }^{13} \mathrm{C}$ values of lipids from $\mathrm{AOM}$ communities are mainly influenced by isotope fractionation during $\mathrm{AOM}$ and the $\delta^{13} \mathrm{C}$ value of the carbon sourced from methane (Summons et al., 1994; Riou et al., 2010), though other environmental parameters such as substrate availability and temperature are also known to influence lipid $\delta^{13} \mathrm{C}$ signals. $\delta^{13} \mathrm{CCH}_{4}$ values are typically low and the additional isotope fractionation during AOM results in AOM-derived lipid, with $\delta^{13} \mathrm{C}$ values $\ll-50 \%$. Our reference site showed $\delta^{13} \mathrm{C}$ values of archaeal and bacterial lipids that were not conspicuously depleted. This indicates a low or negligible standing stock of AOM microbes at this site. Here, archaeal and bacterial lipids likely originated from processes other than AOM (e.g., organic matter degradation by heterotrophs). At site Lomvi 893MC, the $\delta^{13} \mathrm{C}$ values of archaeal and bacterial lipids were not as negative as at the other three sites. The differences in the $\delta^{13} \mathrm{C}$ signature of archaeol with respect to the source methane $\left(\delta^{13} \mathrm{C} \mathrm{CH}_{4}=-57.8 \%\right.$ in core Lomvi 893MC and $-62.9 \%$ in core Lunde $886 \mathrm{MC}$; Panieri et al., 2017), were slightly lower in core Lomvi 893MC than in core Lunde 886MC (Fig. 5a). This may reflect an overprint by lipids that are not related to AOM, which supports our assumption that the mini-fracture in core Lomvi $893 \mathrm{MC}$ and the associated AOM community developed rather recently. We do not know the source methane $\delta^{13} \mathrm{C}$ value for core Lomvi 008PC, but, assuming a uniform source methane value of $-55 \%$ for the whole Lomvi pockmark area, the highest $\Delta \delta^{13} \mathrm{C}$ values were observed at Lomvi 008PC (Fig. 5). Together with the biomarker evidence for a significant AOM community and the rapid depletion of sulfate in this core, this indicates that AOM biomass (and probably AOM activity) is more dominant at the Lomvi 008PC coring site than at the other two investigated sites. Although the AOM community seemed lower at Lunde $886 \mathrm{MC}$, the $\Delta \delta^{13} \mathrm{C}$ values were similar to the ones observed at Lomvi 008PC. This suggests that here, despite the lower methane flux, AOM communities also dominated the overall microbial community.

\section{Summary and conclusion}

At the Lomvi pockmark, we found evidence for advective methane transport, with an indication for different onsets of gas seepage at the different coring sites, while at the coring site at the Lunde pockmark, methane transport is dominated by diffusion (Fig. 6). Together with the porewater geochemical constraints, the distribution of ${ }^{13} \mathrm{C}$-depleted lipid biomarkers underscores that the pockmark methane biogeochemistry is differentially affected by the advective vs. diffusive transport regimes. Our data show that high standing stocks of AOM communities thrive in surface sediments where methane concentrations are high, while in sediments 
where methane availability is limited, only a comparably low AOM biomass developed. The co-occurrence of a welldeveloped AOM standing stock and high $\mathrm{CH}_{4}$ concentrations, however, cannot be considered a universal rule. Despite high methane concentrations in sediments featuring a mini-fracture, sediments contained a comparably low standing stock of AOM communities, and geochemical signals for AOM activity were rather subtle. Methane transport through mini-fractures is advective and fractures thus represent important conduits for methane, facilitating the development of an active AOM community. Yet a high biomass of the slowgrowing AOM communities require that advective transport has proceeded for an extended period of time after the onset of sediment fracturing (i.e., the development of AOM communities temporally lags behind). Our data suggest that the mini-fracture detected here opened rather recently, whereas methane transport at the other coring sites probably started much earlier. Mini-fractures are rarely recognized because they are below the resolution of seismic imaging tools and their detection is mostly incidental. Our study clearly highlights their relevance for benthic methane dynamics and adds to the very limited knowledge on the potential contribution of fracture networks to benthic carbon cycling.

Data availability. All the data in the paper can be found in the Supplement.

Supplement. The supplement related to this article is available online at: https://doi.org/10.5194/bg-16-2221-2019-supplement.

Author contributions. HY and GP collected biomarker samples. WLH, MET, and SS contributed to porewater sampling and analyses. HN and MFL supported lipid biomarker analyses. HY wrote the majority of the paper. GP and HN supervised the research. All authors contributed to the discussion of data and the writing of the paper at different stages.

Competing interests. The authors declare that they have no conflict of interest.

Acknowledgements. We would like to acknowledge the captains, crews and all scientists on board R/V Helmer Hanssen cruise CAGE 15-2 and R/V G.O. Sars cruise P1606. We are especially thankful for Towcam operation by the team from Woods Hole Oceanographic Institution (WHOI) MISO (Multidisciplinary Instrumentation in Support of Oceanography) as well as ROV operation by the Ægir pilots. We would further like to thank Carsten J. Schubert and Serge Robert from EAWAG for the support during carbon isotopic analyses. This work was supported by the Research Council of Norway through its Centres of Excellence funding scheme (project number 223259). The publication charges for this article have been funded by a grant from the publication fund of UiT The Arctic University of Norway in Troms $\varnothing$.

Financial support. This research has been supported by the Research Council of Norway (grant no. 223259).

Review statement. This paper was edited by Aninda Mazumdar and reviewed by Wriddhiman Ghosh and one anonymous referee.

\section{References}

Anders, M. H., Laubach, S. E., and Scholz, C. H.: Microfractures: A review, J. Struct. Geol., 69, 377-394, https://doi.org/10.1016/j.jsg.2014.05.011, 2014.

Berndt, C., Feseker, T., Treude, T., Krastel, S., Liebetrau, V., Niemann, H., Bertics, V. J., Dumke, I., Dunnbier, K., Ferre, B., Graves, C., Gross, F., Hissmann, K., Huhnerbach, V., Krause, S., Lieser, K., Schauer, J., and Steinle, L.: Temporal constraints on hydrate-controlled methane seepage off Svalbard, Science, 343, 284-287, https://doi.org/10.1126/science.1246298, 2014.

Bernhard, J. M. and Panieri, G.: Keystone Arctic paleoceanographic proxy association with putative methanotrophic bacteria, Sci. Rep.-UK, 8, 10610, https://doi.org/10.1038/s41598-018-288713, 2018.

Blees, J., Niemann, H., Wenk, C. B., Zopfi, J., Schubert, C. J., Jenzer, J. S., Veronesi, M., and Lehman, M. F.: Bacterial methanotrophs drive the formation of a seasonal anoxic benthic nepheloid layer in an alpine lake, Limnol. Oceanogr., 59, 1410-1420, https://doi.org/10.4319/lo.2014.59.4.1410, 2014.

Boetius, A. and Suess, E.: Hydrate Ridge: a natural laboratory for the study of microbial life fueled by methane from near-surface gas hydrates, Chem. Geol., 205, 291-310, https://doi.org/10.1016/j.chemgeo.2003.12.034, 2004.

Bohrmann, G., Ahrlich, F., Bergenthal, M., Bünz, S., Düßmann, R., Ferreira, C., Freudenthal, T., Fröhlich, S., Hamann, K., Hong, W.-L., Hsu, C., Johnson, J. E., Kaszemeik, K., Kausche, A., Klein, T., Lange, M., Lepland, A., Malnati, J., Meckel, S., MeyerSchack, B., Noorlander, K., Panieri, G., Pape, T., Reuter, M., Riedel, M., Rosiak, U., Schmitdt, C., Schmidt, W., Seiter, C., Spagnoli, G., Stachowski, A., Stange, N., Wallmann, K., Wintersteller, P., Wunsch, D., and Yao, H.: R/V MARIA S. MERIAN Cruise Report MSM57, Gas Hydrate Dynamics at the Continental Margin of Svalbard, Reykjavik - Longyearbyen - Reykjavik, 29 July-07 September 2016, MARUM - Zentrum für Marine Umweltwissenschaften, Fachbereich Geowissenschaften, Universität Bremen, 1-204, 2017.

Briggs, B. R., Pohlman, J. W., Torres, M., Riedel, M., Brodie, E. L., and Colwell, F. S.: Macroscopic biofilms in fracture-dominated sediment that anaerobically oxidize methane, Appl. Environ. Microb., 77, 6780-6787, https://doi.org/10.1128/AEM.00288-11, 2011.

Bünz, S., Polyanov, S., Vadakkepuliyambatta, S., Consolaro, C., and Mienert, J.: Active gas venting through hydrate-bearing sediments on the Vestnesa Ridge, offshore W-Svalbard, Mar. Geol., 332-334, 189-197, https://doi.org/10.1016/j.margeo.2012.09.012, 2012. 
Cline, J. D.: Spectrophotometric Determination of Hydrogen Sulfide in Natural Waters, Anal. Chem., 21, 1005-1009, 1969.

Egeberg, P. K. and Dickens, G. R.: Thermodynamic and pore water halogen constraints on gas hydrate distribution at ODP Site 997 Blake Ridge, Chem. Geol., 153, 53-79, 1999.

Egger, M., Riedinger, N., Mogollón, J. M., and Jørgensen, B. B.: Global diffusive fluxes of methane in marine sediments, Nat. Geosci., 11, 421-425, https://doi.org/10.1038/s41561-018-01228, 2018.

Elvert, M., Boetius, A., Knittel, K., and Jørgensen, B. B.: Characterization of Specific Membrane Fatty Acids as Chemotaxonomic Markers for Sulfate-Reducing Bacteria Involved in Anaerobic Oxidation of Methane, Geomicrobiol. J., 20, 403-419, https://doi.org/10.1080/01490450303894, 2003.

Elvert, M., Hopmans, E. C., Treude, T., Boetius, A., and Suess, E.: Spatial variations of methanotrophic consortia at cold methane seeps: implications from a high-resolution molecular and isotopic approach, Geobiology, 3, 195-209, 2005.

Emery, D. and Myers, K. J.: Sequence Stratigraphy, Blackwell Science, Oxford, 1996.

Fischer, D., Mogollón, J. M., Strasser, M., Pape, T., Bohrmann, G., Fekete, N., Spiess, V., and Kasten, S.: Subduction zone earthquake as potential trigger of submarine hydrocarbon seepage, Nat. Geosci., 6, 647-651, https://doi.org/10.1038/ngeo1886, 2013.

Friedman, M.: Fractur in Rock, Rev. Geophys. Space Phys., 13, 352-358, 1975.

Gabrielsen, R. H., Aarland, R.-K., and Alsaker, E.: Identification and spatial distribution of fractures in porous, siliclastic sediments, in: Structrual Geology in Reservoir Characterization, edited by: Coward, M. P., Daltaban, T. S., and Johnson, H., Geological Society, London, 49-64, 1998.

Gieske, J., Gamo, T., and Brumsack, H.: Chemical methods for interstitial water analysis aboard joides resolution ocean drilling program, Texas A\&M University Technical Note 15, 1991.

Grasshoff, K., Kremling, K., and Ehrhardt, M.: Methods of Seawater Analysis, Wiley-VCH, Weinheim/Deerfield Beach, Florida, 1999.

Haeckel, M., Boudreau, B. P., and Wallmann, K.: Bubbleinduced porewater mixing: A 3-D model for deep porewater irrigation, Geochim. Cosmochim. Ac., 71, 5135-5154, https://doi.org/10.1016/j.gca.2007.08.011, 2007.

Hong, W.-L., Sauer, S., Panieri, G., Ambrose, W. G., James, R. H., Plaza-Faverola, A., and Schneider, A.: Removal of methane through hydrological, microbial, and geochemical processes in the shallow sediments of pockmarks along eastern Vestnesa Ridge (Svalbard), Limnol. Oceanogr., 61, S324-S343, https://doi.org/10.1002/lno.10299, 2016.

Hong, W.-L., Schmidt, C., Yao, H., Wallmann, K., Rae, J., Lepland, A., Torres, M., Plaza-Faverola, A., Latour, P., Bunz, S., and Bohrmann, G.: Fracture-Induced Fluid Migration in an Arctic Deep Water Pockmark: Porewater Geochemistry from the MEBO Drilling (MSM57) in Vestnesa Ridge (Svalbard), Goldschmidt Abstract, Paris, 2017a.

Hong, W. L., Torres, M. E., Carroll, J., Cremiere, A., Panieri, G., Yao, H., and Serov, P.: Seepage from an arctic shallow marine gas hydrate reservoir is insensitive to momentary ocean warming, Nat. Commun., 8, 15745, https://doi.org/10.1038/ncomms15745, $2017 b$.
Hong, W. L., Torres, M. E., Portnov, A., Waage, M., Haley, B., and Lepland, A.: Variations in Gas and Water Pulses at an Arctic Seep: Fluid Sources and Methane Transport, Geophys. Res. Lett., 45, 4153-4162, https://doi.org/10.1029/2018gl077309, 2018.

Hovland, M., Gardner, J. V., and Judd, A. G.: The significance of pockmarks to understanding fluid flow processes and geohazards, Geofluids, 2, 127-136, https://doi.org/10.1046/j.14688123.2002.00028.x, 2002.

Knies, J., Daszinnies, M., Plaza-Faverola, A., Chand, S., Sylta, Ø., Bünz, S., Johnson, J. E., Mattingsdal, R., and Mienert, J.: Modelling persistent methane seepage offshore western Svalbard since early Pleistocene, Mar. Petrol. Geol., 91, 800-811, https://doi.org/10.1016/j.marpetgeo.2018.01.020, 2018.

Knittel, K. and Boetius, A.: Anaerobic oxidation of methane: progress with an unknown process, Annu. Rev. Microbiol., 63, 311-334, https://doi.org/10.1146/annurev.micro.61.080706.093130, 2009.

Levin, L. A., Baco, A. R., Bowden, D. A., Colaco, A., Cordes, E. E., Cunha, M. R., Demopoulos, A. W. J., Gobin, J., Grupe, B. M., Le, J., Metaxas, A., Netburn, A. N., Rouse, G. W., Thurber, A. R., Tunnicliffe, V., Van Dover, C. L., Vanreusel, A., and Watling, L.: Hydrothermal Vents and Methane Seeps: Rethinking the Sphere of Influence, Front. Mar. Sci., 3, https://doi.org/10.3389/fmars.2016.00072, 2016.

Moss, C. W. and Lambert-Fair, M. A.: Location of Double Bonds in Monounsaturated Fatty Acids of Campylobacter cryaerophila with Dimethyl Disulfide Derivatives and Combined Gas Chromatography-Mass Spectrometry, J. Clin. Microbiol., 27, 1467-1470, 1989.

Nauhaus, K., Albrecht, M., Elvert, M., Boetius, A., and Widdel, F.: In vitro cell growth of marine archaeal-bacterial consortia during anaerobic oxidation of methane with sulfate, Environ. Microbiol., 9, 187-196, https://doi.org/10.1111/j.14622920.2006.01127.x, 2007.

Nichols, P. D., Guckert, J. B., and White, D. C.: Determination of monounsaturated fatty acid double-bond position and geometry for microbial monocultures and complex consortia by capillary GC-MS of their dimethyl disulphide adducts, J. Microbiol Meth., 5, 49-55, 1986.

Niemann, H. and Elvert, M.: Diagnostic lipid biomarker and stable carbon isotope signatures of microbial communities mediating the anaerobic oxidation of methane with sulphate, Org. Geochem., 39, 1668-1677, https://doi.org/10.1016/j.orggeochem.2007.11.003, 2008.

Niemann, H., Elvert, M., Hovland, M., Orcutt, B., Judd, A., Suck, I., Gutt, J., Joye, S., Damm, E., Finster, K., and Boetius, A.: Methane emission and consumption at a North Sea gas seep (Tommeliten area), Biogeosciences, 2, 335-351, https://doi.org/10.5194/bg-2-335-2005, 2005.

Niemann, H., Duarte, J., Hensen, C., Omoregie, E., Magalhães, V. H., Elvert, M., Pinheiro, L. M., Kopf, A., and Boetius, A.: Microbial methane turnover at mud volcanoes of the Gulf of Cadiz, Geochim. Cosmochim. Ac., 70, 5336-5355, https://doi.org/10.1016/j.gca.2006.08.010, 2006a.

Niemann, H., Losekann, T., de Beer, D., Elvert, M., Nadalig, T., Knittel, K., Amann, R., Sauter, E. J., Schluter, M., Klages, M., Foucher, J. P., and Boetius, A.: Novel microbial communities of the Haakon Mosby mud volcano 
and their role as a methane sink, Nature, 443, 854-858, https://doi.org/10.1038/nature05227, 2006b.

Niemann, H., Fischer, D., Graffe, D., Knittel, K., Montiel, A., Heilmayer, O., Nöthen, K., Pape, T., Kasten, S., Bohrmann, G., Boetius, A., and Gutt, J.: Biogeochemistry of a low-activity cold seep in the Larsen B area, western Weddell Sea, Antarctica, Biogeosciences, 6, 2383-2395, https://doi.org/10.5194/bg-6-23832009, 2009.

Niemann, H., Linke, P., Knittel, K., MacPherson, E., Boetius, A., Bruckmann, W., Larvik, G., Wallmann, K., Schacht, U., Omoregie, E., Hilton, D., Brown, K., and Rehder, G.: Methanecarbon flow into the benthic food web at cold seeps - a case study from the Costa Rica subduction zone, PLoS One, 8, e74894, https://doi.org/10.1371/journal.pone.0074894, 2013.

Panieri, G., Fornari, D. J., Serov, P., Astrom, E. K. L., PlazaFaverola, A., Mienert, J., and Torres, M.: Gas hydrate, carbonate cruists, and chemosynthetic organisms on Vestnesa Ridge Pockmark - Preliminary findings, Fire in the Ice, 15, 14-17, 2015.

Panieri, G., Bünz, S., Fornari, D. J., Escartin, J., Serov, P., Jansson, P., Torres, M. E., Johnson, J. E., Hong, W., Sauer, S., Garcia, R., and Gracias, N.: An integrated view of the methane system in the pockmarks at Vestnesa Ridge, $79^{\circ} \mathrm{N}$, Mar. Geol., 390, 282-300, https://doi.org/10.1016/j.margeo.2017.06.006, 2017.

Plaza-Faverola, A., Bünz, S., Johnson, J. E., Chand, S., Knies, J., Mienert, J., and Franek, P.: Role of tectonic stress in seepage evolution along the gas hydrate-charged Vestnesa Ridge, Fram Strait, Geophys. Res. Lett., 42, 733-742, https://doi.org/10.1002/2014g1062474, 2015.

Reeburgh, W. S.: Oceanic Methane Biogeochemistry, Chem. Rev., 107, 486-513, 2007

Riedel, M., Collett, T. S., Malone, M. J., and the Expedition 311 Scientists: Proc. IODP, 311: Washington, DC (Integrated Ocean Drilling Program Management International, Inc.), https://doi.org/10.2204/iodp.proc.311.2006, 2006.

Riou, V., Bouillon, S., Serrão Santos, R., Dehairs, F., and Colaço, A.: Tracing carbon assimilation in endosymbiotic deep-sea hydrothermal vent Mytilid fatty acids by ${ }^{13} \mathrm{C}$-fingerprinting, Biogeosciences, 7, 2591-2600, https://doi.org/10.5194/bg-7-25912010, 2010.

Sahling, H., Römer, M., Pape, T., Bergès, B., dos Santos Fereirra, C., Boelmann, J., Geprägs, P., Tomczyk, M., Nowald, N., Dimmler, W., Schroedter, L., Glockzin, M., and Bohrmann, G.: Gas emissions at the continental margin west of Svalbard: mapping, sampling, and quantification, Biogeosciences, 11, 6029-6046, https://doi.org/10.5194/bg-11-6029-2014, 2014.

Sauer, S., Hong, W.-L., Knies, J., Lepland, A., Forwick, M., Klug, M., Eichinger, F., Baranwal, S., Crémière, A., Chand, S., and Schubert, C. J.: Sources and turnover of organic carbon and methane in fjord and shelf sediments off northern Norway, Geochem. Geophy. Geosy., 17, 4011-4031, https://doi.org/10.1002/2016gc006296, 2016.

Seeberg-Elverfeldt, J., Schluter, M., Feseker, T., and Kolling, M.: Rhizon sampling of porewaters near the sediment-water interface of aquatic systems, Limnol. Oceanogr., 3, 361-371, 2005.

Smith, A. J., Mienert, J., Bunz, S., and Greinert, J.: Thermogenic methane injection via bubble transport into the upper Arctic Ocean from the hydrate-charged Vestnesa Ridge, Svalbard, Geochem. Geophy. Geosy., 15, 1945-1959, 2014.
Steinle, L., Knittel, K., Felber, N., Casalino, C., de Lange, G., Tessarolo, C., Stadnitskaia, A., Sinninghe Damsté, J. S., Zopfi, J., Lehmann, M. F., Treude, T., and Niemann, H.: Life on the edge: active microbial communities in the $\mathrm{Kryos} \mathrm{MgCl}_{2}-$ brine basin at very low water activity, ISME J., 12, 1414-1426, https://doi.org/10.1038/s41396-018-0107-z, 2018.

Summons, R. E., Jahnke, L. L., and Roksandic, Z.: Carbon isotopic fractionation in lipids from methanotrophic bacteria: Relevance for interpretation of the geochemical record of biomarkers, Geochim. Cosmochim. Ac., 58, 2853-2863, https://doi.org/10.1016/0016-7037(94)90119-8, 1994.

Timmers, P. H., Gieteling, J., Widjaja-Greefkes, H. C., Plugge, C. M., Stams, A. J., Lens, P. N., and Meulepas, R. J.: Growth of anaerobic methane-oxidizing archaea and sulfate-reducing bacteria in a high-pressure membrane capsule bioreactor, Appl. Environ. Microb., 81, 1286-1296, https://doi.org/10.1128/AEM.03255-14, 2015.

Tobin, H., Vannucchi, P., and Meschede, M.: Structure, inferred mechanical properties, and implications for fluid transport in the décollement zone, Costa Rica convergent margin, Geology, 29, 907-910, https://doi.org/10.1130/00917613(2001)029<0907:SIMPAI>2.0.CO;2, 2001.

Torres, M. E., McManus, J., Hammond, D. E., De Angelis, M. A., Heeschen, K. U., Colbert, S. L., Tryon, M. D., Brown, K. M., and Suess, E.: Fluid and chemical fluxes in and out of sediments hosting methane hydrate deposits on Hydrate Ridge, OR, I: Hydrological provinces, Earth Planet. Sc. Lett., 201, 525-540, 2002.

Torres, M. E., Mix, A. C., and Rugh, W. D.: Precise $\delta^{13} \mathrm{C}$ analysis of dissolved inorganic carbon in natural waters using automated headspace sampling and continuous-flow mass spectrometry, Limnol. Oceanogr.-Meth., 3, 349-360, https://doi.org/10.4319/lom.2005.3.349, 2005.

Treude, T., Boetius, A., Knittel, K., Wallmann, K., and Jørgensen, B.: Anaerobic oxidation of methane above gas hydrates at Hydrate Ridge, NE Pacific Ocean, Mar. Ecol.-Prog. Ser., 264, 1-14, 2003.

Ussler, W. and Paull, C. K.: Rates of anaerobic oxidation of methane and authigenic carbonate mineralization in methanerich deep-sea sediments inferred from models and geochemical profiles, Earth Planetary Sc. Lett., 266, 271-287, https://doi.org/10.1016/j.epsl.2007.10.056, 2008.

Waage, M., Portnov, A., Serov, P., Bünz, S., Waghorn, K. A., Vadakkepuliyambatta, S., Mienert, J., and Andreassen, K.: Geological Controls on Fluid Flow and Gas Hydrate Pingo Development on the Barents Sea Margin, Geochem. Geophy. Geosy., 20, 630-650, https://doi.org/10.1029/2018GC007930, 2019.

Wegener, G., Niemann, H., Elvert, M., Hinrichs, K. U., and Boetius, A.: Assimilation of methane and inorganic carbon by microbial communities mediating the anaerobic oxidation of methane, Environ. Microbiol., 10, 2287-2298, 2008.

Weinberger, J. and Brown, K.: Fracture networks and hydrate distribution at Hydrate Ridge, Oregon, Earth Planet. Sc. Lett., 245, 123-136, https://doi.org/10.1016/j.epsl.2006.03.012, 2006.

Whiticar, M.: Carbon and hydrogen isotope systematics of bacterial formation and oxidation of methane, Chem. Geol., 161, 291-314, 1999.

Yao, H., Panieri, G., Knies, J., Belt, S. T., Koseoglu, D., and Niemann, H.: Past Methane Emissions in the Storfjordrenna Gas Hydrate-Bearing Mounds, Goldschmidt Abstract, Paris, 2017. 
Zhang, Y., Maignien, L., Zhao, X., Wang, F., and Boon, N.: Enrichment of a microbial community performing anaerobic oxidation of methane in a continuous high-pressure bioreactor, BMC Microbiol., 11, 137, https://doi.org/10.1186/1471-2180-11-137, 2011. 